\title{
Kierkegaard and the problem of special relationships: Ferreira,
}

\section{Krishek and the 'God filter'}

Kierkegaard's Works of Love has often been accused of being unable to deal adequately with 'special relationships'. The charges against Kierkegaard typically take one of two forms. Sometimes he is said to overlook special relationships, viewing all others as indistinguishable neighbours, such that the distinctiveness of any given other is ignored. On this view, we are commanded to have the same relationship to our spouse, closest friends and even ourselves that we have to a neighbour who is a stranger. Or - a weaker charge - he is sometimes said to undervalue the moral importance of distinctiveness and special relationships.

This debate has recently re-emerged in a fresh form in an interesting disagreement between M. Jamie Ferreira and Sharon Krishek (Ferreira 2001, 2010; Krishek 2009). In this article, I shall explore this dispute before proposing, as a solution to Krishek's concerns, a defence of Kierkegaard's position centred around the image of God as a 'filter' through which our loves must pass.

Ferreira's defence of Kierkegaard against these charges presents the Dane as less radical (and thus less objectionable) than his critics allege. But this comes at a price: some key passages are insufficiently addressed. This part of Krishek's critique of Ferreira is valuable. Yet overall, I argue, Krishek ends up unfairly condemning a key aspect of Works of Love. Krishek valorises 'self-concerned, natural and spontaneous' desires (Krishek 2009: 117), but leaves largely unanswered the question of which of these we should endorse, and why. As a way of solving the problem Krishek sees with Kierkegaard's account - that Kierkegaard gives a 
conflicted account of 'preferential' loves - I suggest that we should focus on the idea of God as the 'middle term' in love. We should understand this to mean, in significant part, that God acts as a kind of 'filter' through which any kind of love - neighbourly as well as preferential - must pass before it is commended. A key advantage of this model is that we do not need to assume, pace Krishek, that the purified versions of any two manifestations of love are identical. I shall argue that Krishek has an excessively strong reading of what Kierkegaard means by saying that two loves are 'the same'. This leads her unnecessarily to conflate equality of value with equality of treatment. Finally, while recognising that Krishek raises some important questions for Ferreira's defence of Kierkegaard, I outline a possible response. This is based on Kierkegaard's idea that, like the law and love, neighbour love is only a sketch until brought to fruition in any given manifestation of concrete love. I supplement this with some illustrations Ferreira gives of how Kierkegaard's account 'preserves the concrete', including the recognition of concrete differences between particular others. Ultimately, I claim, this aspect of Kierkegaard's position in Works of Love can indeed be defended from Krishek's critique.

\section{Jamie Ferreira: Kierkegaard's advocate}

Ferreira discusses dimensions of our problem in several places. ${ }^{1}$ For instance, she considers in some detail the image of 'blindness' towards distinctions between individuals used in Works of Love. Does commending such blindness towards the neighbour endorse 'an abstract relation to another whose distinctiveness is irrelevant and who is effectively interchangeable' (Ferreira 2001: 54)? The key question is whether the 'particular individuals' of whom Kierkegaard speaks 'are seen as distinctive people embedded in a context of distinctive

\footnotetext{
${ }^{1}$ Space limitations mean that, regrettably, I shall have to confine myself here largely to criticism of both Ferreira and Krishek, notwithstanding the many merits of their respective books. However, I shall draw on Ferreira in a more positive spirit in section 4.
} 
relations rather than particular abstract, representative, and interchangeable individuals' (ibid.).

Ferreira argues that the purpose of the imagery of being 'blind' to dissimilarities and distinctions is to ensure that we do not 'contract the scope of the commandment; such blindness guarantees that no one can be excluded' (Ferreira 2001: 55). The worry is that preference 'for characteristics that are similar to ours, or the kind we value, can lead to exclusion' (Ferreira 2001: 56). Here she notes the following passage: 'If you hold together ... with some other people of a particular class and with a particular condition in life ... the things of this world will ... tempt you comparatively in showing partiality' (WL 78/SKS9 $84)^{2}$

But here is this passage in full:

'If you hold together (for alliance is not of the good) with some other people of a particular class and with a particular condition in life, even if it is only with your wife, the things of this world will tempt. Even if in your eyes they do not mean much, they tempt you comparatively in showing partiality, they tempt you perhaps for her sake' (Ibid., my emphases).

The references to a person's wife - omitted by Ferreira - are revealing. There is a clear implication in the full passage that preferential love can itself be precisely the source of the blindness to kinship which concerns Kierkegaard. Ferreira says that Kierkegaard's 'claim that "the neighbour is the common watermark, you see it only by means of eternity's light when it shines through the dissimilarity" [WL 89/SKS9 94] - which has often been taken to be an excessive emphasis on the "essence" of human nature - looks different when taken in the

\footnotetext{
${ }^{2}$ All references to Works of Love are to the following editions: Kierkegaard 1995 (English, cited as WL) and 2004 (Danish, cited as SKS9).
} 
context of his rejection of what George Eliot calls "love of the clan"” (Ferreira 2001: 56). In a footnote, Ferreira explains that Eliot's objection is to opposing the 'clan' to the rest of mankind. But while this is fine as far as it goes, it has not addressed our question about either overlooking or underestimating the moral importance of 'natural' bonds such as friendship, marriage and family. We would all presumably agree that the tribalism which bothers Eliot is not Christian. But Ferreira's account underplays the fact that Kierkegaard here sees precisely spousal love - not just such 'clannish' tribalism - as the threat to neighbour-love.

Even if Ferreira succeeds in showing that Kierkegaard does not intend that we view the neighbour as an abstraction (Ferreira 2001: 62) this is nevertheless consistent with the conclusion that his account of how natural affections be transformed in the light of neighbour-love leaves much to be desired. This account is underdeveloped. Ferreira claims, quite reasonably, that 'Kierkegaard's dismissal of the relevance of "distinctions" warns against the limits of preference but does not entail the rejection of preferential relations. The point ... was to "preserve neighbor-love" in erotic love and friendship.' (Ferreira 2001: 62). But it is one thing to acknowledge space for preferential relations, quite another to show how this preservation is to be performed. And the worry is that Kierkegaard falls at this latter fence. Ultimately, I think Kierkegaard can be defended here. But for the time being, while Ferreira is right that we can reject the charge that Kierkegaard ignores special relations, the more nuanced charge that he undervalues their moral importance is still very much alive.

Ferreira considers the charge that 'in Kierkegaard's ethic of love others are not able to be loved directly, for themselves' (Ferreira 2001: 71) in the context of her discussion of the idea that God is the 'middle term' in our relationships with others. Consider the following passage: 
'As soon as a love-relationship does not lead me to God, and as soon as I in the loverelationship do not lead the other to God, then the love, even if it were the highest bliss and delight of affection, even if it were the supreme good of the lovers' earthly life, is still not true love. This the world cannot get into its head, that God in this way not only becomes the third party in every relationship of love but really becomes the sole object of love, so that it is not the husband who is the wife's beloved, but it is God, and it is the wife who is helped by the husband to love God, and conversely, and so on. The merely human view of love can never go beyond mutuality: the lover is the beloved, and the beloved is the lover. Christianity teaches that such a love has not yet found its true object - God. ... Therefore, to love another person is to help that person to love God, and to be loved is to be helped' (WL 120-1/SKS9 124).

Ferreira asks precisely the question that will be on most readers' lips: 'What does it mean for God to be the "sole object of love", so that the wife's beloved is not the husband but God?' (Ferreira 2001: 71). She interprets this as meaning that 'God should remain the judge of what true love is' (ibid.). In other words, 'God's view of what is "good" is the standard for what we should do for the other or want the other to do for us.' (ibid.) What does it means for God to be the 'middle term'? On Ferreira's view, it is that 'as soon as one leaves out the Godrelationship, the participants' merely human definition of what they want to understand by loving, what they want to require of each other ... becomes the highest judgement' (WL 112/SKS9 116).

But is this too pessimistic and mistrustful about human nature? Even if God gives a crucial measure that would otherwise be lacking, it does not follow that without that measure, the 'merely human' will descend into the lower rather than ascend to the higher possibilities of human nature. Here Kierkegaard's colours seem to be nailed to a particular theological mast, 
taking a stance opposed to the idea that grace completes nature. While this is unsurprising from within the Lutheran tradition, it is not a position we are obliged to endorse. ${ }^{3}$

Ferreira reads the idea of God as the middle term as not being 'in any way prejudicial to genuine and direct love of neighbor or beloved' (Ferreira 2001: 72) provided one shares Kierkegaard's twin theological assumptions. First, that 'God is love and so represents what true love is' (Ferreira 2001: 72). Second, that we are creatures: 'we all belong to God' (ibid.). In other words, God's love both provides the model for our love and sets limits on how we can love. But these limits do not ipso facto damage proper, genuine, direct love of our neighbours, friends or beloveds. Rather, the point is that 'the relationships among human beings ought [never] and may never be such that the one worships and the other is the one worshipped' (Ferreira 2001: 73-4, citing WL 125/SKS9 128). ${ }^{4}$ That is, the beloved must never take the place of God in our lives. However, in the passage quoted earlier on how God is 'the sole object of love', Kierkegaard seems to be saying something stronger.

Ferreira offers a similarly deflationary reading of Kierkegaard's notorious discussion of 'hating' the beloved. She reads the passage about the New Testament demand of being willing 'out of love and in love to hate the beloved' (WL 108/SKS9 112) as meaning simply the following. Suppose what my beloved asks of me is inconsistent with what God asks of me. Then my refusal effectively to put her ahead of God means that she (insofar as she fails to understand God as the 'middle term'), 'will see as hate [my] refusal to always give what ... she asks' (Ferreira 2001: 74, my emphasis). (This claim would be more plausible if we substituted 'will' with 'might'.) In other words, I am not being told actually to hate my beloved. Rather, what is being demanded of me is 'being willing, when appropriate, to

\footnotetext{
${ }^{3}$ This question is at the heart of Jack Mulder's thoughtful discussion of the differences between Kierkegaard and Aquinas on the 'order of love' (whether or not we should prioritise those closest to us). See Mulder 2010: 67-97.

${ }^{4}$ I have amended the translation here for the sake of clarity. Thanks to an anonymous referee for bringing the relevant ambiguity to my attention.
} 
"seem" as if to hate the other, or being willing, when appropriate, to be hated by the other' (Ferreira 2001: 75).

Again, Ferreira's interpretation arguably makes Kierkegaard more palatable than the text fully warrants. And even though her Kierkegaard is less extreme than some, she still makes an important concession: 'Perhaps Kierkegaard exaggerates what he calls the "collision" between two conceptions of love, "the divine conception and the merely human conception" (ibid., citing WL 110/SKS 9 114).

Ferreira returns to the problem of 'special relationships' in her discussion of the deliberation 'Love is a matter of conscience'. Her strategy remains the same: to attempt to defend Kierkegaard from the persistent criticism that he gives an inadequate account of such relationships. Ferreira continues to maintain that for Kierkegaard preferential loves are not excluded; it is simply that neighbour-love needs to be preserved at the heart of erotic love and friendship. But once again, her reading of Kierkegaard seems to gloss over some problematic passages.

Ferreira notes the following crucial passage:

'Christianity has not come into the world to teach this or that change in how you are to love your wife and your friend in particular, but to teach how you are to love all human beings universally-humanly. It is in turn this change that Christianly changes erotic love and friendship.' (WL 142-3/SKS9 144)

She connects this with a slightly later passage:

'Christianity has not changed anything in what people have previously learned about loving the beloveds, the friend, etc., has not added a little or subtracted something, but it has changed everything, has changed love as a whole. Only insofar as a change of 
inwardness in erotic love and friendship results from this fundamental change, only to that extent has it changed these.' (WL 147/SKS9 148)

To the second passage, Kierkegaard immediately adds: 'This it has done by making all love a matter of conscience' (WL 147/SKS9 148).

We might wonder whether this second passage obscures precisely the question at issue. One of the key questions is precisely what difference is made to erotic love and friendship by the idea that the lover or friend is 'first and foremost the neighbour'. So it becomes crucial to ask: what is this 'change of inwardness' of which Kierkegaard speaks?

Ferreira reads the two passages as follows: 'the only radical change involved is the change of making love, even when it includes erotic love and friendship, a "matter of conscience".' (Ferreira 2001: 90) She explicitly denies that Kierkegaard is requiring us to forgo the "natural drives and inclinations' (Ferreira 2001: 90-1) of erotic love and friendship. (Provided, I assume, that they are not inconsistent with central Christian teachings.) But this underlines the importance of her next question. What should we make of 'the admittedly "strange, chilling inversion" by which "in loving the beloved we are first to love the neighbour" (WL 141/SKS9 142)?' (Ferreira 2001: 91)

Again, Ferreira seeks to justify Kierkegaard's position here, insisting that 'what it means to say that someone is "first and foremost the neighbour" is that with respect to each person we must consult with our conscience' (Ferreira 2001: 91). What this turns out to mean is that since the other belongs primarily to God, not ourselves,

'a man can no more take advantage of his wife, because she is his wife, than of another neighbour. We cannot make a sex object out of our wife or husband; we cannot emotionally or physically abuse our spouse because, however intimate and specific the 
relationship is, each remains a neighbour, an equal before God. The apparent abstractness of the claim, "Each one of us is a human being and then in turn the distinctive individual that he is in particular, but to be a human being is the fundamental category" [WL 141/SKS9 143] is meant to guarantee the fundamental respect appropriate to our equality before God. The "first, then" language is not meant to be taken as a temporal qualifier. There is no instant at which we are only the abstract determinant "human being"; we are always in some kind of special relation, even if it is only the relation of being someone's child.' (Ferreira 2001: 92, my emphasis)

Ferreira claims that Kierkegaard's central point is that 'the Christian change in all love' (ibid.) is that love becomes a matter of conscience. Thus although 'Christianity makes a change in erotic love and friendship', this change is simply that it introduces conscience, and thus it does not involve 'preventing them from being erotic love and friendship' (ibid.).

Will this do? As it stands, I don't think so. First, to say that Christianity introduces conscience is to take a quite unfair view of the possibilities of, for instance, pagan friendship. Indeed, conscience is a significant feature of many accounts of friendship in the ancient world (see Lippitt 2007). To 'take advantage' of one's friend or spouse is to fail qua friend or spouse. It is not only to fail qua neighbour. So the category of neighbour is not strictly necessary to explain what is objectionable about such advantage-taking.

Second, what of the claim that erotic love and friendship are unchanged 'externally' by the crucial 'internal' change Kierkegaard mentions? This requires closer scrutiny. Ferreira's interpretation leaves an important question unanswered. She notes the important claim that Christianity only recognises 'only one kind of love, the spirit's love' (WL 143/SKS9 145), 'but this can lie at the base of and be present in every other expression of love' (WL 
146/SKS9 147-8). From this point of view, we should not speak of different kinds of love but different manifestations of this one form of love. Ferreira claims:

'Neighbor love, Kjerlighed, is not a "higher" love that should replace or be added to erotic love and friendship ... the goal is to preserve love for the neighbour in erotic love and friendship. ... Nonpreferential love is to "permeate" all expressions of love - to transform them - yet not in the sense of adding something to them, as if you could love the beloved or friend adequately by yourself' (Ferreira 2001: 94).

But exactly what is the difference between such love 'permeating' our natural loves and being an 'addition' to them? In what follows, I shall offer my own answer to this question.

But I shall do so by first considering Krishek's recent criticism of Ferreira.

\section{Sharon Krishek on Kierkegaard, Ferreira and special relationships}

The central focus of Krishek's book (Krishek 2009) is Elskov, erotic or romantic love. ${ }^{5}$ Although appreciative of significant elements of Kierkegaard's account of love in Works of Love, Krishek argues that there is a fundamental confusion, contradiction or inadequacy in that text's account of the relationship between neighbour love and romantic love. ${ }^{6}$ I shall

\footnotetext{
${ }^{5}$ The main burden of Krishek's book is to argue for the value of a view of (romantic) love inspired by the account of faith found in Kierkegaard's Fear and Trembling. In this article, I shall be concerned only with one small part of Krishek's overall project: her argument that Kierkegaard's account of the relationship between neighbourly love and preferential love in Works of Love is seriously flawed. Thus my disagreements with Krishek in what follows should certainly not be taken to imply that my overall view of her book is negative, any more than my criticisms of Ferreira above are intended to detract from the overall excellence of Ferreira's commentary on Works of Love.

${ }^{6}$ Krishek seems to equivocate as to which of these claims she wants to make. As Ferreira puts it in a review of her book, 'it is unclear what the status of the criticism is. At times it seems that Krishek is uncovering an inconsistency in Works of Love; at other times, it seems that she is suggesting an inadequacy. In the first case, her work would be put forth as a corrective of Works of Love (admittedly informed by Kierkegaard's own better insights in Fear and Trembling), while in the second case it would serve as a complement to Works of Love's inadequate presentation of romantic love. In the first case, her charge would be
} 
focus here exclusively on her critique of Works of Love and of Ferreira's attempted defence of that text. I shall argue that, in this part of her account, Krishek is unfair to Kierkegaard for two related reasons. First, I think she misunderstands the implications of his claim that Christianity recognises only 'one kind of love'. Second, I think she wrongly assumes that Kierkegaard's commitment to equality of value commits him to assumptions about equality of treatment.

Krishek draws attention to a key passage in the very first deliberation of Works of Love. Here Kierkegaard claims that human love originates in God's love:

'Just as the quiet lake originates deep down in hidden springs no eye has seen, so also does a person's love originate even more deeply in God's love. If there were no gushing spring at the bottom, if God were not love, then there would be neither the little lake nor a human being's love. Just as the quiet lake originates darkly in the deep spring, so a human being's love originates mysteriously in God's love. Just as the quiet lake invites you to contemplate it but by the reflected image of darkness prevents you from seeing through it, so also the mysterious origin of love in God's love prevents you from seeing its ground.' (WL 9-10/SKS9 17-8)

This enables Krishek 'cautiously' to sketch the following picture:

'Love is a driving power implanted in us by God, but it is hidden. It is the basis for all the possible manifestations of love; but in itself, this fundamental power is unfathomable. ... [Thus] we can inquire only into its various manifestations: ... the way that this fundamental love expresses itself in our works ... These works may sometimes bear recognisable fruit, but not necessarily.' (Krishek 2009: 110-11)

that Works of Love contains an irresolvable tension; in the second case, her charge would be that Works of Love contains a lop-sided emphasis on self-denial.' (Ferreira 2010) 
Krishek thus interprets Kierkegaard as seeing four 'levels' of love. First, God as the source of love. Second, love itself, as the 'mysterious power' placed in us by God and which is the 'hidden ground of our works'. Third, the 'manifestations' or 'works' of love themselves. And fourth (but only sometimes), their fruits (Krishek 2009: 111). Drawing on Ferreira, Krishek claims that Kierkegaard is often ambiguous as to whether Kjerlighed refers to the first of these, the second, or the neighbour-love we are commanded to manifest (Krishek 2009: 111, citing Ferreira 2008: 107). Krishek uses Kjerlighed to refer only to 'the love placed in us by God', seeing it as the 'hidden ground' of any possible manifestation of love: romantic, as well as neighbourly. Beyond this, she then notes the distinctions, now standard in this literature, between erotic love and friendship ('special loves') as preferential, and neighbourlove as non-preferential, the latter rooted in equality and based on 'self-denial'.

In her subsequent discussion, Krishek implicitly assumes that the opposite of 'self-denial' is selfishness, a term that she doesn't fully unpack. ${ }^{7}$ What she does say strikes me as problematic. She cites a passage in which Kierkegaard contrasts 'immediacy' and 'eternity':

'What a difference there is between the play of feelings, drives, inclinations and passions, in short, that play of the powers of immediacy, that celebrated glory of poetry in smiles or in tears, in desire or in want - what a difference between this and the earnestness of eternity, the earnestness of the commandment in spirit and in truth, in honesty and self-denial!' (WL 25/SKS9 33)

On the back of this, she claims:

\footnotetext{
${ }^{7}$ This is far from uncommon. 'Selfishness' is central to the discussion of several commentators (including Ferreira 2001; Krishek 2009; Walsh 2005 and Welz 2008). But none of these commentators is explicit about what they mean by the term - and nor is Kierkegaard.
} 
'It seems reasonable to assume that Kierkegaard considers those elements ('feelings, drives, inclinations and passions ... the powers of immediacy') to constitute the selfishness that distinguishes between preferential love and neighbourly love, because they are indeed concerned exclusively with the self and its gratification.' (Krishek 2009: 114)

But Kierkegaard's overall point here surely cannot be to condemn 'feelings, drives, inclinations and passions' per se. Indeed, part of the process of Christian 'upbuilding' is that one becomes the kind of person in whom the passion of neighbour-love is manifested. I think Krishek here misreads the passage from which she quotes. The context of this passage is Christianity's 'apparent contradiction' that love is a duty (WL 24/SKS9 31). This view 'did not arise in any human being's heart' (WL 24/SKS9 32) and is thus foreign to the pagan who has not been 'spoiled' by the delusion that he is a Christian in virtue of living in Christendom (WL 25/SKS9 32). Just before the passage Krishek quotes, Kierkegaard says: 'Love had existed also in paganism, but this obligation to love is a change of eternity - and everything has become new' (WL 25/SKS9 33). ${ }^{8}$ The difference to which Kierkegaard is alluding, then, is between the passions (etc.) of a Christian (on the one hand) and being controlled by 'the powers of immediacy' in 'smiles or tears', such that one's 'immediate' 'desires' and 'wants' are in control of one (on the other). In other words, it is not 'feelings, drives, inclinations and passions' per se that are the problem. It is being controlled by the wrong ones, or in the wrong way. Since the discussion is about what has been altered by love being commanded ('You shall love your neighbour as yourself'), the question that matters is as follows. Now that love is commanded in this way (and is not just a matter of natural inclination), what difference does this make to our feelings, drives, inclinations and passions? How do they need to change from their 'pagan' state? One might think of much of Kierkegaard's writing

\footnotetext{
${ }^{8}$ Cf. 2 Corinthians 5: 17.
} 
(including Works of Love) as a series of attempts to 'educate the heart' in the light of this 'new' state of affairs. Or - more precisely - to educate the heart in light of rediscovering this newness in the midst of 'Christendom', a world that has forgotten how 'new' and radical true Christianity is. In sum, the key point is not that feelings, drives, inclinations and passions' per se are the problem. The problem is rather not developing any such feelings, drives, inclinations and passions beyond a 'pagan' worldview. Kierkegaard's position is not that passions etc. are necessarily 'concerned exclusively with the self and its gratification'.?

So what difference does this commanded neighbour-love make? In aiming to defend her interpretation, Krishek continues: 'this fits well with the logic that differentiates between preferential love and neighbourly love: ... Kierkegaard defines neighbourly love as selfdenial's love ... and this, quite reasonably, must oppose the kind of love that is focused on the self' (Krishek 2009: 114).

But we need to be careful here: much depends upon exactly what 'focused on the self' means. Such language threatens to obscure the fact that there is often an inextricable link between proper self-love and love of others such that these cannot be teased apart. As Alasdair MacIntyre observes:

'We do indeed as infants, as children and even as adolescents, experience sharp conflicts between egoistic and altruistic impulses and desires. But the task of education is to transform and integrate those into an inclination towards both the common good and our individual goods, so that we become neither self-rather-than-other-regarding nor other-rather-than-self-regarding, neither egoists nor altruists, but those whose passions and inclinations are directed to what is both our good and the good of others.

\footnotetext{
${ }^{9}$ As Ferreira notes in her review, Krishek 'seems to ignore the fact that the text of Works of Love provides a number of critical affirmations of our drives and inclinations and needs, places where Kierkegaard tries to correct a negative "misunderstanding" about our drives and inclinations; he rules out a misplaced "either/or"" (Ferreira 2010).
} 
Self-sacrifice, it follows, is as much of vice, as much of a sign of inadequate moral development, as selfishness.' (MacIntyre 1999: 160)

In other words, a vital part of proper self-love may involve combining the good for oneself and the good for others in a way that makes talk of 'self-sacrifice', 'self-denial' and egoism versus altruism pretty unhelpful. Sally B. Purvis gives a good example with respect to a mother's love for her baby: 'the mother's need may be to feed the child, comfort her, rock him, etc.' (Purvis 1991: 27).

What this enables us to see is twofold. First, that Krishek is on to something important: we should not valorise a conception of proper self-love that obliges us to get 'beyond' the self transcend all its desires - completely. But, second, that the idea of 'self-denial' needs to be treated very carefully.

Qualifying somewhat her earlier remarks, Krishek recognises that the second love commandment itself means that Kierkegaard's position cannot be that 'inclinations and desires and everything connected to the well-being of the self are to be eliminated when one is to love properly (that is, in the neighbourly way)' (Krishek 2009: 114-5). She goes on to recognise the need 'to distinguish between at least two different ways of relating to the self, between two kinds of self-love: the kind of self-love referred to in the commandment, and the kind of self-love Kierkegaard considers as selfish' (Krishek 2009: 115).

Krishek's subsequent treatment of the problem is an attempt to qualify the position of Ferreira. Krishek agrees with Ferreira on several key points. First, that the distinction we need is between proper and selfish self-love. Second, that proper self-love (the kind that can be 'applied to our relationship to the neighbour') is based on 'respect' and 'wishing the good for ourselves' (ibid.). She also cites approvingly Ferreira's distinction between 'a "selfish", exclusive love of self, which is at odds with the good of the other, and a "proper", inclusive 
love of the self, which both encompasses the good of the other and is the measure of the good of the other' (Ferreira 2001: 35; cited in Krishek 2009: 115). (The latter is the measure of the good of the other in the sense that the 'as yourself' of the commandment sets up proper selflove as the model for proper love of others.)

Krishek asks a good question as to whether merely not being at odds with the good of the other is sufficient to give Ferreira the distinction she wants:

'Taking this [not being at odds with the good of the other] as our guiding rule does not explain ... why passionate romantic love ... should be considered by Kierkegaard to be selfish ... After all, from the point of view of one's neighbour there is nothing offensive (in terms of respect and wishing his well-being) in loving one's beloved passionately ... Kierkegaard's objection to preferential love goes beyond a strictly blatant violation of the good of the neighbour' (ibid.).

She then goes on to modify Ferreira's account by distinguishing not two (as Ferreira does) but three kinds of self-love:

a) Selfish self-love: self-love which is 'at odds with good of the other': it involves 'using the other as a means for one's selfish satisfactions or acting towards achieving one's own good regardless of the effect it has on the other'.

b) Proper qualified self-love: a 'restricted' form of self-love which is that to which the commandment refers. This is 'understood in terms of respect and wishing one's wellbeing, in a narrow sense of "well-being" (that is, a well-being stripped of most of its "embodied" aspects, such as responsiveness and sensitivity to inclinations, desires and preferences)'.

c) Proper unqualified self-love: 'Acting to fulfil one's well-being, in a broader sense of “well-being" (which includes sensitivity to the self's inclinations, desires and 
preferences), with a constant consideration of the good of the other. That is, fulfilling one's own "self-focused" concerns so long as they are not "at odds with the good of the other".' (Krishek 2009: 116)

Will this give us the distinction that we need? I don't think so. For exactly what is Krishek claiming about self-love and neighbour-love in b)? She says this is the kind of self-love referred to in the commandment. But if that were so, then the way in which I should love my neighbour (when I love him as I love myself) would be in a 'restricted' way in which I do not wish him to respond to his inclinations, desires and preferences (because in such 'qualified' self-love I have denied my own). That hardly sounds plausible.

Krishek aims to argue that self-love b) and c) are not 'in harmony':

'Neighbourly love, which in [Kierkegaard's] understanding is self-denial's love, can work well with self-love only when self-love is understood in the manner of $b$ ). Of course, this does not mean that self-love in the manner of c) should be ruled out; but as long as self-denial is the dominant structure of the love which Kierkegaard advocates here, self-love in the manner of c) - that is, self-love which is concerned also with the gratification of one's self-focused wishes (even if it does not come explicitly at the expense of the other) - should at least be set aside as marginal or secondary' (Krishek 2009: 116).

I believe that Kierkegaard does overplay the concept of self-denial, and so I think that there is definitely something to this aspect of Krishek's critique. However, Krishek fails explicitly to acknowledge that not all of one's 'self-focused' concerns can be valorised - even when they are not at odds with the good of the other. For instance, a desire for vainglorious honour and prestige may dominate a person's life. Even if nobody else loses out as a result of such selffocus, that hardly justifies it. Krishek has not told us enough about which self-focused 
concerns are in, which are out, and why. She asks whether Kierkegaard allows for 'an affirmation that unapologetically takes into consideration self-concerned, natural and spontaneous desires, or does he, ultimately, consider this aspect of the self to be "selfish"?' (Krishek 2009: 117, my emphasis). Surely the answer to this question depends upon which such desires Krishek has in mind. Even if we reject Kierkegaard's more extreme oppositions to 'the world', it would still be perfectly in order for him to claim that these desires need to be in accordance with the good and with Christian teaching. There are forms of preferential love that will pass this test, and forms that will not.

A major part of Krishek's charge against Kierkegaard here seems to be that the love valorised in Works of Love is too spiritualised, at the expense of our nature as embodied creatures. But the love valorised in Works of Love does not deny our embodiment, as the centrality of the parable of the Good Samaritan to that text makes clear. It is crucial that the Samaritan binds the injured man's wounds and pays for his stay at the inn, rather than just - as Ferreira nicely puts it - throwing him 'spiritual reading for his stay in the ditch' (Ferreira 2001: 34). ${ }^{10}$

Krishek claims that the ambivalence to preferential love at the heart of Works of Love is largely overlooked in the secondary literature. Citing Sylvia Walsh's concession that Kierkegaard 'does not seem to recognize any ability on the part of natural love to love unselfishly' (Walsh 1988: 248; cited in Krishek 2009: 119), she rejects as inadequate Walsh's attempt to dissolve the tension by claiming that although we love our significant others 'differently', 'this difference is not essential, since we love them fundamentally as we love others, that is, as a neighbor' (ibid.). Walsh's way of putting this, without any further explanation, does seem to want to have its cake and eat it. Walsh is certainly on to something: the idea that the beloved must be first and foremost the neighbour. But she claims that such

\footnotetext{
${ }^{10}$ I am assuming here that Krishek's talk of 'embodiment' is not only a coy reference to our sexual desires.
} 
neighbourly love is for Kierkegaard 'the decisive factor in the transformation of erotic love that rids it of selfish exclusivity and establishes equality in love while preserving special relations' (Walsh 1988: 241, cited in Krishek 2009: 119). And Krishek’s question is, effectively, how does it do this? How can we rid ourselves of what Kierkegaard calls 'selfishness' 'without this resulting in the elimination of the special, preferential loves that we want to keep': our preferences, desires and inclinations towards those we love preferentially (Krishek 2009: 120)? Relatedly, 'how can the same love (neighbourly love) be at the same time equal and special? If neighbourly love should be directed equally at everybody, what does this love look like when it is directed at those special people in our lives? Is this love still the same? What then makes this special love special?' (ibid.)

At this point, Krishek tackles Ferreira ('my most important opponent' (ibid.)) head on. She notes Ferreira's claims that 'preferential love ... should not be the determinant of responsibility for the other' (Ferreira 2001: 46, cited in Krishek 2009: 120) and that 'Love of neighbour is distinguished from preferential love precisely because neighbor is the category of equality before God and preferential love does not do justice to equality' (Ferreira 2001: 44, cited in Krishek 2009: 121). The warning here is against exclusion: the only problem with preferential love being the danger it poses in this respect.

But, Krishek asks, how do we unpack this? Can preferential love really be 'subsumed under neighbourly love without compromising either the meaning of preferential love (as preferential) or the rigorousness of the "commitment to human equality"?' (Krishek 2009: 122). If neighbour love (presented by Kierkegaard as essentially non-preferential) is 'the essential model for love', what does this imply for 'the essential element of preferentiality in special loves'? (ibid.) How can this avoid contradiction? Surely not making exceptions rules out the possibility of a 'hierarchy in the way in which one loves'? 'If taken seriously ... the 
"radical commitment to equality", that Works of Love posits as the ground for any form of love, implies the exclusion of preferential love' (ibid.).

Relatedly, Krishek claims: 'One can love one's beloved "above all others" and yet be sensitive and responsible and caring for one's neighbour and help him in his need. There is no contradiction here. Kierkegaard, however, insists that there is. Note that he couples "above all others" with "in contrast to all others": in his view, to love someone "more" necessarily entails blindness towards the rest.' (Krishek 2009: 123)

How should we respond to this? The early passage in which Kierkegaard runs together these two distinct ideas (WL 19/SKS9 27) is indeed unfortunate. But this conflation is not central to his point, and his overall position in Works of Love does not need that conflation. Kierkegaard's real worry is the slippery slope from 'above all others' to 'in contrast to all others', as we shall shortly see. Discussing an annoying neighbour in the flat upstairs whom she does 'not really like', Krishek recognises that neighbour-love requires her to 'care about him, to see him as an equal human being, to feel compassion towards him and to help him if he is in need' (Krishek 2009: 123). Thus, she claims, preferential love does not ipso facto blind her to this duty. That is surely true. But I do not find in Kierkegaard the necessity claim that Krishek attributes to him. To say that 'preferential' love involves loving one other 'in contrast to all others' is indeed an exaggeration. But what Kierkegaard is really doing is warning of a 'slippery slope' danger similar to that which C. S. Lewis notes in his discussion of friendship in The Four Loves. A brief discussion of Lewis will clarify matters.

Lewis claims that 'every real friendship is a sort of secession, even a rebellion' (Lewis 1960: 80). On its negative side this signals a real danger: 'Friendship (as the ancients saw) can be a school of virtue; but also (as they did not see) a school of vice. It is ambivalent. It makes 
good men better and bad men worse.'(Lewis 1960: 80) ${ }^{11}$ The important point for our purposes is that this ambivalent aspect of friendship is intimately related to cliquishness: 'a wholesale indifference or deafness' to outside opinion (Lewis 1960: 81). José Ortega y Gasset signals this as a feature of romantic love: 'the world does not exist for the lover. His beloved has dislodged and replaced it' (Ortega y Gasset 1957: 50). This is certainly one of Kierkegaard's worries, yet Lewis shows that a more subtle version of the same danger is present in friendship. At its worst, 'Everyone who is not in the circle must be shown that he is not in it. Indeed the Friendship may be "about" almost nothing except the fact that it excludes.' (Lewis 1960: 85). Hence the slippery slope that troubles Lewis: 'From the innocent and necessary act of excluding to the spirit of exclusiveness is an easy step; and thence to the degrading pleasure of exclusiveness' (Lewis 1960: 86). At the bottom of this slope, '[t]he common vision which first brought us together may fade quite away. We shall be a coterie that exists for the sake of being a coterie; a little self-elected (and therefore absurd) aristocracy, basking in the moonshine of our collective self-approval' (ibid.).

What Kierkegaard is worried about is precisely that, and its romantic equivalents (where as Ortega suggests, the danger is typically heightened). This does indeed seem like a genuine threat to the love of other neighbours. Even if we are not thus made 'blind' (in a negative sense) to our neighbours, we can nevertheless be led to downgrade their importance. This downgrading comes out in Krishek's own example, when she says: 'loving my friend preferentially does mean that the well-being of my friend is of a more focused concern to me, and sadly - since we are limited creatures (in time and abilities) who cannot dedicate our maximal efforts to everyone - it also means that I choose my friend (by virtue of my

\footnotetext{
${ }^{11}$ Actually, Lewis is not being fair to 'the ancients' here. In arguably the most celebrated discussion of friendship in the ancient world, the Nicomachean Ethics, Aristotle makes precisely this point.
} 
preference which gives my friend his special status) above my neighbour.' (Krishek 2009:

This claim has some plausibility provided we stick at this level of abstraction, but far less so if we fill in some details. I am troubled by Krishek's talk of a 'hierarchy' in love, based on preference. Her idea seems to be that that ceteris paribus, I will choose my beloved or friend over a stranger, and that it is normally right and proper so to do. But ceteris paribus conditions are always artificial: the particulars of the circumstances are always important to deciding what is demanded of us. If the choice is between the upstairs neighbour asking me to the pub when I have already committed to a friend, then I can certainly politely turn down his offer, explaining my prior commitments. No moral dilemma or failure in neighbour-love has arisen here. However, if the neighbour gets in first, I accept his offer and promise to meet him later, but then receive an offer from my friend (whose company I expect to prefer), then I do not see what justifies breaking my promise to the neighbour: the mere fact that I prefer the company of my friend is certainly not sufficient justification to break my promise. (Would Krishek claim otherwise? Under what conditions does her 'hierarchy' apply?) The point, then, is that Ferreira is right that preference cannot be the 'determinant of responsibility for the other'.

But here is the crux of the matter. Krishek claims:

'The result of the demand to love in the same way (in the neighbourly, non-preferential, equal way) all the different objects of love in our lives, then, is that we leave no real room for the (existing) differences between preferential and non-preferential loves.' (Krishek 2009: 124)

This does not follow. Kierkegaard is not committed to the claim that we must love identically each of the objects of love in our lives. Indeed, this cannot be what he means: for instance, it 
is surely implausible to think that for Kierkegaard my love for God should be identical to my love for my annoying upstairs neighbour. The object itself makes a difference to the nature of the love, but Krishek has not shown that this is inconsistent with Kierkegaard's claims. The fact that everyone is my neighbour does not mean that the nature of the love for my friend or beloved, as opposed to the annoying guy upstairs, is identical. When Krishek asks what a neighbourly manifestation of preferential love looks like, she explores an important issue, but, I suggest, in a misleading way. Her precise questions, we noted above, are: 'If neighbourly love should be directed equally at everybody, what does this love look like when it is directed at those special people in our lives? Is this love still the same?' But these are, I think, the wrong questions, for reasons I shall now seek to explain.

\section{The God filter}

I submit that Kierkegaard's position is not that a love identical in the case of each individual other person should be 'directed equally at everybody'. Rather, part of what is meant by God being the 'middle term' is that 'God' is a kind of filter through which each of our loves needs to be passed. ${ }^{12}$ A major component of this filter is that the other is 'first and foremost the neighbour'. The model I have in mind is as follows. Each distinct, individual love (whether preferential or not) needs to pass the 'God filter' test. For instance: Does my love for Sylvie merely serve my selfish desires? Does my friendship with Joe require me to act in a way that I know to be inconsistent with the good? Is the specific demand this stranger makes on me inconsistent with what Christianity teaches? And so on. If a given love does pass the test,

\footnotetext{
${ }^{12}$ More fully: for Kierkegaard, God is both the object of our love and (in a sense to be discussed in section 4 below) offers the pattern for our loves.
} 
then it has been 'purified' (up to a point) in the sense that it has been stripped of its 'sinful' elements. ${ }^{13}$

Two caveats are necessary here. First, to say the above is not to deny that our judgements on these matters are always going to be defeasible. Self-deception will remain a constant danger. What is being commended is the kind of test necessary for any given love to count as (relatively) 'pure': nothing is being claimed about the infallibility of any such test. Relatedly - and this is the second point - I don't mean to imply by a phrase like 'stripped of its sinful elements' that the filter gets rid of original sin. However, even if all human actions and intentions have the taint of original sin, this does not imply that there is no point in asking of some specific relationship whether my reasons for entering it are selfish, self-centred or otherwise problematic.

This model has the significant advantage that with regard to Krishek's objection to Ferreira, there is no reason to suppose that, once it has gone through the filter, any given instance of 'purified' romantic love (or friendship) would be identical to Samaritan-like love of a stranger in need. As we have seen, what worries Krishek is precisely this: that the Kierkegaard of Works of Love is committed to the identity of such loves. Now, the point of the filter is to rid any given manifestation of love of its harmful 'impurities'. But we would not suppose that the 'purified' residue of two different liquids run through a filter would be identical. In the same way, my love for my beloved remains importantly different from my love for the annoying guy upstairs - even after each has passed through the filter. On this model, then, Krishek's question - what makes special loves special? - does not arise. It arises only if we assume that Kierkegaard is committed to the idea of the 'sameness of the love itself' (Krishek 2009: 126). One can understand what has led Krishek to this assumption,

${ }^{13}$ Kierkegaard writes: 'love the beloved faithfully and tenderly, but let love for the neighbor be the sanctifying element in your union's covenant with God' (WL 62/SKS 9 69). 
given Kierkegaard's remark that Christianity recognises 'only one kind of love, the spirit's love' (WL 143/SKS9 147). But exactly what kind of 'sameness' is at issue here? The loves are 'the same' only in a relatively weak sense: the passage in which Kierkegaard uses this phrase is not concerned with metaphysical identity. Rather, the emphasis is on 'the spirit's love' as that on which Christianity focuses its attention:

'The worldly or merely human point of view recognizes a great many kinds of love and is well informed about the dissimilarity of each one and the dissimilarity between each particular one and the others. ... With Christianity the opposite is the case. It recognizes really only one kind of love, the spirit's love, and does not concern itself much with working out in detail the different ways in which this fundamental universal love can manifest itself' (WL 143/SKS9 147)

In other words, to say that Christianity 'recognizes really' only the spirit's love is to say that Christianity is interested above all else in this key common denominator in all commendable manifestations of love. Such love might be found both in my love for my romantic beloved and my love for a stranger, but this does not imply that the common denominator is all that there is in these manifestations of love. They will be very different in practice and in detail. My love for my beloved and my love for the homeless stranger - once through the 'filter' are 'the same' love only (but importantly) in the sense that they are both free of the relevant impurities.

I think Krishek's mistake is to assume that the equality of value on which Kierkegaard insists (since all neighbours are equal before God) implies the need for an equality of treatment which makes it impossible to distinguish my love for my beloved from my love for the stranger. But Kierkegaard, I submit, neither conflates these two kinds of equality nor draws this inference: he is committed to equality of value, but that does not imply that he needs to 
be committed to equality of treatment. So, provided her love is purified in the relevant way, Kierkegaard would be quite happy for Krishek to love her husband in a different way to that in which she loves a stranger. Note that on the view I am defending here, love for the stranger - a manifestation of love we typically think of as being non-preferential - also needs to go through the 'God filter'. And this seems right: it is no good the Samaritan robbing another passerby in order to pay for the injured man's stay at the inn. So although Kierkegaard thinks we are 'naturally' constituted such that preferential loves are most likely to threaten 'purified' neighbour love (and so focuses his energy there), I think he would endorse the view that nonpreferential love is not ipso facto 'pure'.

\section{4. 'Preserving the concrete'}

To flesh out the claims above, let us finally consider, in a bit more detail, how Kierkegaard 'preserves the concrete' or the specifics of particular 'special relationships'. We can usefully draw on Ferreira in doing so, to shore up our response to Krishek's objections above.

Key to the response available to Ferreira would be the moves Kierkegaard makes in those deliberations chiefly concerned with the second part of the third deliberation's distinction between 'law' and 'love' (Ferreira 2001: 100). Ferreira notes that Kierkegaard describes 'the distinction between "the law" and "love" as a contrast between a[n artist's] "sketch" and its fulfilment in the "work".' (ibid.) Moreover, Kierkegaard adds that the sketch 'remains "indefinite" until the work is finished, when we can say that 'there is not the slightest indefiniteness, not of a single line nor of a single point' (WL 104/SKS9 108). Is it not reasonable to suppose that something similar is at work between the category of the neighbour - the 'common watermark' of humanity that troubles those critics who accuse Kierkegaard of excessive abstraction - and the specific, concrete aspects and manifestations of love with which, Ferreira argues, the bulk of the book is concerned? 
The 'You shall love' of the commandment and the very category of the neighbour is given to us in the parts of the first series concerned with clarifying the concepts and scope of the commandment. But according to Ferreira, such clarification of scope is only a preliminary to an increasing focus on concreteness. ${ }^{14}$ Perhaps then, supplementing my 'God filter' imagery above, neighbour-love is not only the liquid that 'permeates' other liquids (such as romantic love, friendship and self-love) in their 'purified' form, but is - to switch metaphors - only a 'sketch' until it is brought to fruition in any given manifestation of ('purified') love. And some such manifestations will be examples of romantic love, Krishek's central concern.

This second metaphor (of sketches and fully realised artistic works) is one dimension of the centrality of 'vision' in this deliberation (amongst others). Ferreira suggests: 'probably the most decisive positive discussion of ethics as a kind of seeing is found in this fourth deliberation, where to be ethical is to see the other just as he or she is, in all his or her distinctive concreteness' (Ferreira 2001: 106). If it is right that this is central to Kierkegaard's overall purpose, then it follows that one's lover cannot just be one's neighbour, and there are further reasons to resist Krishek's objection to the alleged lack of enthusiasm with which Kierkegaard embraces concreteness or 'special' loves.

Ferreira argues that Kierkegaard preserves this concreteness in several ways. First, he urges us to avoid becoming victims of our own fantasies. He urges us to love the person we see, not 'the self-generated image of the other person' (Ferreira 2001: 109); 'an imaginary idea of how we think or could wish that this person should be' (WL 164/SKS9 164).

\footnotetext{
${ }^{14}$ Ferreira claims that the tripartite second deliberation constitutes 'law': 'the description of a rule for determining the category "neighbor" - "all" has the force of "no exceptions". The purpose of these chapters is not to delineate the character of a substantive response to the other but to delimit a category by stipulating that no one can be excluded from this category on the basis of difference or dissimilarity ... The analysis of the rule (the sketch or the skeleton) is not meant to give us a complete picture of his view of love.' (Ferreira 2001: 102).
} 
Second, 'loving the person one sees' does not imply being utterly blind to their faults. Love can be challenging as well as accepting, but it can do this only if it loves the actual person it sees (Ferreira 2001: 110-1). In this context, Ferreira draws our attention to Kierkegaard's reminder of Christ's comment on Peter in the wake of the latter's betrayal.

'He did not say, "Peter must first change and become another person before I can love him again." No, he said exactly the opposite, "Peter is Peter, and I love him. My love, if anything, will help him to become another person." Therefore he did not break off the friendship in order perhaps to renew it if Peter would have become another person; no, he preserved the friendship unchanged and in that way helped Peter to become another person.' (WL 172/SKS9 172)

Third, Ferreira claims that the message that God's love should be the model for 'true human love' implies that the latter, like the former, should focus on 'concrete differences' (Ferreira 2001: 112). She draws our attention to part of the following passage:

'With what infinite love nature or God in nature encompasses all the diverse things in existence! Just recollect what you yourself have so often delighted in looking at, recollect the beauty of the meadows! There is no difference in the love, no, none - yet what a difference in the flowers! Even the least ... little flower disregarded by even its immediate surroundings, the flower you can hardly find without looking carefully - it is as if this, too, had said to love: Let me become something in myself, something distinctive. And then love has helped it to become its own distinctiveness, but far more beautiful than the poor little flower had ever dared to hope for. What love! First, it makes no distinction, none at all; next ... it infinitely distinguishes itself in loving the diverse. Wondrous love! For what is as difficult as to make no distinction at all in 
loving, and if one makes no distinction at all, what is as difficult as making

distinctions!' (WL 269-70/SKS9 268, my emphasis)

He then goes on to contrast such love with that of 'us human beings - rigid, domineering, cold, partisan, small-minded, capricious' (WL 270/SKS9 268), wondering what would become of the beauty of the meadows under such attitudes.

This is a crucial passage for the dispute between Ferreira and Krishek. I have quoted more of it than either of them, for reasons that will shortly become apparent. Quoting part of the same passage and referring to Ferreira's discussion of it, Krishek objects: 'The problem with this model of love is not that it implies sameness in the object of love (or, in Ferreira's terms, blindness to differences and concreteness) - but rather than it implies the sameness of the love itself' (Krishek 2009: 126). I have resisted this conclusion above, so I need now to explain what I think is wrong with Krishek's reading of this specific passage.

If we focus only on the phrase 'no difference in the love', we could indeed reach Krishek's conclusion. But we need a more careful reading of the whole passage, and I argue that such a reading takes us much closer to Ferreira's position. It seems clear that the intention of the overall passage is that the love described 'makes no distinction' in the sense that it finds everyone to be of intrinsic value. Yet the passage also clearly implies that this love celebrates differences and acts accordingly. (This is Ferreira's point.) If this love is the model for our love, then the point seems to be this. Let us start with the conclusion Ferreira draws: 'genuine human love, emulating divine love, should love the differences and build up differentially, responding to different needs.' (Ferreira 2001: 112-3) This is fine as far as it goes - but we need to say more. The italicised passage - which, interestingly, neither commentator cites draws our attention to two distinct difficulties. First, that of making no distinctions. This is difficult because of our natural preferences for our beloveds and our friends. Second, that of 
making distinctions having made no distinctions! Understanding this is trickier. But it seems to be a reference to precisely the tension that Ferreira thinks Kierkegaard is trying to hold together, and that Krishek thinks is the crux of the problem. The point is this. Having committed myself to making no distinctions (because everyone is my neighbour), I now need to make distinctions (because what is required of me to bring out the 'beauty' in this neighbour (say, my beloved) is different from what is required to bring it out of that neighbour (say, the homeless stranger begging for cash).) Is this 'the same love'? Well, yes and no. Yes, in the sense that these two different manifestations of love are both permeated by neighbour love. But no, in the sense that my actions and intentions towards the stranger and towards my beloved will be very different, and appropriately so, even though they are both permeated by neighbour love.

Once again, I am not sure what kind of 'sameness' Krishek thinks is implied here. I submit that when Kierkegaard talks of 'making no distinctions', he no more implies the 'sameness' of any two manifestations of love in any problematic sense than does Krishek herself, every time she uses the phrase 'romantic love'. It would be unfairly harsh to charge Krishek with the view that because she brings two different manifestations of love - Sue's love for her husband; Bill's for his wife - under the same heading (romantic love) that she is therefore claiming that these two manifestations of love are metaphysically identical. Clearly they are not. These two manifestations of love do not possess numerical identity, like George Orwell and Eric Blair. Nor are they even qualitatively identical, as if they were two carbon atoms in different substances. They are 'the same' only in the sense that they have significant common features. On my 'God filter' view, both Bill's love for his wife and Sue's for her husband are manifestations of love both of which contain components - if 'purified' - of both neighbour love and romantic love. But the main point of the above passage is precisely that each distinct manifestation of love is importantly different from others, notwithstanding the various 
features they may share. Nevertheless, it is not thereby unreasonable, in common parlance, to call our two instances of love 'romantic love'. Why, then, does Krishek assume that Kierkegaard should be criticised for implying 'sameness' in a similarly weak sense when he claims that Christianity recognizes 'only one kind of love', which as we have argued means, in this context, simply that neighbour love should permeate all manifestations of love?

Consider the following analogy. Suppose a guest wants a mixture of grapefruit juice and orange juice, but does not like the 'bits' contained in the only cartons of such juice that I have. I can get rid of the 'impurities' by passing both juices through an appropriate filter. Both the grapefruit juice (neighbour love) and the orange juice (romantic love) will make it through the filter; both will be contained in the liquid in its 'purified' form (a specific manifestation of romantic love in which the beloved is simultaneously viewed as my neighbour). Krishek is held captive by the picture that romantic love and neighbour love are more like oil and water than these two juices: she cannot seem to see how the one can permeate the other. To push the liquid analogy a bit further, this seems to be because she is worried that neighbour love 'dilutes' romantic love. But as far as I can see, she has provided no compelling reason to support this assumption. Moreover, in further support of an alternative picture, we can draw on a point made by Patrick Stokes. In line with those critics who are concerned about 'the neighbour' just being an abstract category, Stokes acknowledges that 'the ideal needs the concrete for authentic moral concern to be possible' (Stokes 2010: 140). He notes the concern of Kierkegaard's Anti-Climacus about 'fantastic feeling' becoming 'a kind of abstract sentimentality that inhumanly belongs to no human being, but inhumanly, so to speak, sentimentally participates in the fate of one or another abstraction, for example, humanity in abstracto' (Kierkegaard 1980: 31 (translation slightly amended)/SKS11 147). In other words, sympathy with, say, 'the poor' - an amorphous abstraction - is 'not directed at persons ... but only at the idea of persons' (Stokes 2010: 139). 
However, there is another side to this coin: 'the concrete too needs the ideal' (Stokes 2010b: 140). Stokes refers us to the account from The Sickness Unto Death of moral vision as 'a holding in tension of the concrete and the ideal, the actual and the imagined. In our apprehension of the other, the actual person before us is unified in our vision with the ideal claims they make upon us, neither element dissolving or collapsing into the other ... we see not a person and a moral demand, but a person who constitutes, in their concrete specificity, a moral demand in themselves' (Stokes 2010b: 141).

Similarly, I suggest, with the beloved and the neighbour. Here I see not a beloved and a neighbour, but a person who constitutes, in their concrete specificity (one dimension of which is that she is my beloved), a neighbour. If the concrete did not have this ideal (that my beloved is my neighbour as well as my beloved), there would be no guarantee that the various dangers of erotic love and friendship against which Kierkegaard warns might not come into play. That, I submit, is Kierkegaard's position, and it is a far from unreasonable one.

\section{References}

Ferreira, M. Jamie (2001). Love's Grateful Striving: a Commentary on Kierkegaard's Works of Love. Oxford: Oxford University Press.

Ferreira, M. Jamie (2008). The problematic agapeistic ideal - again. In Edward F. Mooney (Ed.), Ethics, Love and Faith in Kierkegaard: philosophical engagements (pp. 93-110). Bloomington: Indiana University Press.

Ferreira, M. Jamie (2010). Review of Krishek 2009. In Notre Dame Philosophical Reviews. http://ndpr.nd.edu/news/24273-kierkegaard-on-faith-and-love/. Accessed 10 December 2011. 
Kierkegaard, Søren (1980). The Sickness Unto Death. Translated by Howard V. and Edna H. Hong. Princeton: Princeton University Press.

Kierkegaard, Søren (1995). Works of Love. Translated by Howard V. and Edna H. Hong. Princeton: Princeton University Press.

Kierkegaard, Søren (2004). Søren Kierkegaards Skrifter. Vol 9: Kjerlighedens Gjerninger. Copenhagen: Søren Kierkegaard Forskningscenteret.

Krishek, Sharon (2009). Kierkegaard on Faith and Love. Cambridge: Cambridge University Press.

Lippitt, John (2007). Cracking the mirror: on Kierkegaard's concerns about friendship. International Journal for Philosophy of Religion, 61, 131-150.

MacIntyre, Alasdair (1999). Dependent Rational Animals: why human beings need the virtues. Chicago: Open Court.

Mulder, Jack Jr. (2010). Kierkegaard and the Catholic Tradition: conflict and dialogue. Bloomington: Indiana University Press.

Ortega y Gasset, José (1957). On love: aspects of a single theme. Trans. Tony Talbot. Cleveland: Meridian.

Purvis, Sally B. (1991). Mothers, neighbours and strangers: another look at agape. Journal of Feminist Studies in Religion, 7-1, 19-34.

Stokes, Patrick (2010). Kierkegaard's Mirrors: Interest, Self and Moral Vision. London: Palgrave. 
Walsh, Sylvia (1988). Forming the heart: the role of love in Kierkegaard's thought. In Richard H. Bell (Ed.), The Grammar of the Heart (pp. 234-256). New York: Harper and Row.

Walsh, Sylvia (2005). Living Christianly: Kierkegaard's Dialectic of Christian Existence. University Park: Pennsylvania State University Press.

Welz, Claudia (2008). Love as Gift and Self-Sacrifice. Neue Zeitschrift für systematische Theologie und Religionsphilosophie, 50, 238-266. 